\title{
Anesthetic management of spinal muscle atrophy type II in a parturient
}

\author{
This article was published in the following Dove Press journal: \\ Local and Regional Anesthesia \\ 6 April 201I \\ Number of times this article has been viewed
}

\author{
Laurent Bollag \\ Christopher Kent \\ Philippe Richebé \\ Ruth Landau \\ Department of Anesthesiology \\ and Pain Medicine, University of \\ Washington Medical Center, Seattle, \\ WA, USA
}

Correspondence: Laurent Bollag Department of Anesthesiology and Pain Medicine, University of Washington Medical Center, 1959 NE Pacific Street, Seattle, WA 98195, USA

$\mathrm{Tel}+\mathrm{I} 2066800333$

Mobile + I 2063277328

Fax + I 2065432958

Email bollag@uw.edu

\begin{abstract}
We report the peripartum management of a 30-year-old wheelchair-bound nullipara woman with spinal muscular atrophy (SMA) type II, including severe restrictive lung disease and Harrington rods. At 38 weeks gestation, she was admitted for an induction of labor with neuraxial analgesia, but she subsequently had to be delivered via cesarean section under general anesthesia. We describe the anesthetic implications of SMA on labor and delivery management and review the available literature.
\end{abstract}

Keywords: muscular atrophy, cesarean section, general and regional anesthesia

\section{Introduction}

Spinal muscular atrophy (SMA) describes a progressive neuromuscular disease of the spinal anterior motor neurons and in $20 \%$ of the cases the motor nuclei of the brainstem. ${ }^{1}$ SMA can display various degrees of skeletal muscle atrophy, muscle weakness, pulmonary insufficiency, autonomic dysfunction, and dysphagia. Pregnancy may worsen symptoms. ${ }^{7}$ It is the leading inherited cause of infant and early childhood mortality, and has an estimated incidence of 1/10,000 live births, and a carrier frequency of $1 / 50$. $^{1}$

In over $95 \%$ of cases of SMA, a genetic autosomal recessive disorder causes a functional loss of the survival motor neuron 1 (SMN1) gene on chromosome V. In $2 \%$ of the cases the transmission appears to be either autosomal dominant, X-linked or sporadic. ${ }^{1}$ SMN1 encodes a protein, SMN, which is crucial to the assembly of the spliceosome, a structure involved in processing mRNA. ${ }^{2}$ It may also mediate mRNA trafficking in axons. SMA is thought to result from insufficient levels of SMN protein in spinal anterior motor neurons. Absence of the gene SMN1 leads to atrophy and death of spinal anterior motor neurons. A second gene, $S M N 2$, located in the centromeric region of the same chromosome, in part modulates the clinical symptoms of SMA. SMA is usually diagnosed by quantifying the presence of the SMN1 gene by polymerase chain reaction (PCR), replacing muscle biopsy or electromyography. The copy number of this weakly expressed homolog may be an important determinant of the severity of the disease. ${ }^{3}$ Consequently, SMA can display various degrees of skeletal muscle atrophy with progressive muscle weakness of the limbs and trunk, pulmonary insufficiency due to scoliosis and chest wall muscle weakness, autonomic dysfunction, and dysphagia, resulting in severe physical disability.

The disease is graded from SMA I-IV based on the severity of these symptoms. SMA type I, first described by the Austrian and German neurologist duo of Werdnig 
and Hoffman ${ }^{4}$ is the most common and severe form of the disease. ${ }^{5}$ It has a rapid, early onset and high mortality, often from an associated pneumonia. It is diagnosed 0-6 months after birth, or even in utero by direct molecular analysis of chorionic villus samples and amniocytes.

SMA type II, intermediate SMA, or in older literature referred to as chronic Werdnig-Hoffman disease is diagnosed in the first 6-24 months after birth. The clinical symptoms are as described in our case report.

In SMA type III, named after the two Swedish neurologists Kugelberg and Welander in $1956^{6}$ and also called juvenile or mild SMA, patients stand and walk by themselves and are usually diagnosed any time between the age of 1 year and adolescence.

SMA type IV has an adult onset (over 18 years), is rare, and produces minimal disabilities.

The literature on the anesthetic management of labor analgesia, cesarean delivery, and the perioperative management of SMA patients is sparse and consists mainly of case reports and one case series published in $1992 .^{7}$ Twelve mothers with SMA type III and IV were followed during their pregnancy, labor, and delivery, out of which three required a cesarean delivery. The mothers' ages ranged from 18-32 years, and they gave birth to a total of 17 babies. Premature labor, prolonged labor, and delayed postpartum recovery were observed in 10 cases. Increased muscle weakness in the second trimester was observed in eight women and persisted postpartum in five women; three cases recovered postpartum. No details of the anesthetic management of these cases were given, and no SMA type II case was in the series.

\section{Case report}

Our patient had SMA type II, which had previously been confirmed by molecular studies during her pregnancy, demonstrating homozygous deletion of axons 7 and 8 on the SMN gene. She had been hoping for a 'natural childbirth' and finally agreed to undergo an elective induction of labor at 38 weeks gestation. She had been able to walk as a child but was now wheelchair bound. She had severe restrictive lung disease (which had slightly worsened during pregnancy: forced expiratory volume in one second $\left[\mathrm{FEV}_{1}\right] 1.23 \mathrm{~L}$ [34\%], forced vital capacity [FVC] 1.35 L [32\%]) due to kypho-scoliosis, which had required a mid-thoracic to sacral Harrington-rods instrumentation at age 10 (Figure 1). Her weight was $48 \mathrm{~kg}$ at term. The airway exam showed Malampati classification class III twice, neck extension was not possible, and flexion reduced. The neck musculature was hypertrophic, possibly to compensate for truncal muscle weakness.

On the day of induction, a lumbar ultrasound was performed with the hope that it would enable visualization of spinal anatomy and facilitate the subsequent provision of neuraxial labor analgesia; however, the usual landmarks could not be identified, therefore ultrasound-guidance proved to be unhelpful. After misoprostol placement for cervical ripening, it was decided to perform an early neuraxial labor analgesic. A combined spinal epidural (CSE) was attempted at the L3-L4 interspace in the sitting position. Using a 17G Tuohy needle with loss of resistance to saline, the epidural space was easily found at $5 \mathrm{~cm}$, but using the needle-throughneedle technique with a $25 \mathrm{G}$ Sprotte spinal needle failed to obtain cerebrospinal fluid (CSF) return. Nevertheless, the epidural catheter (Arrow 19G FlexTipPlus single open end

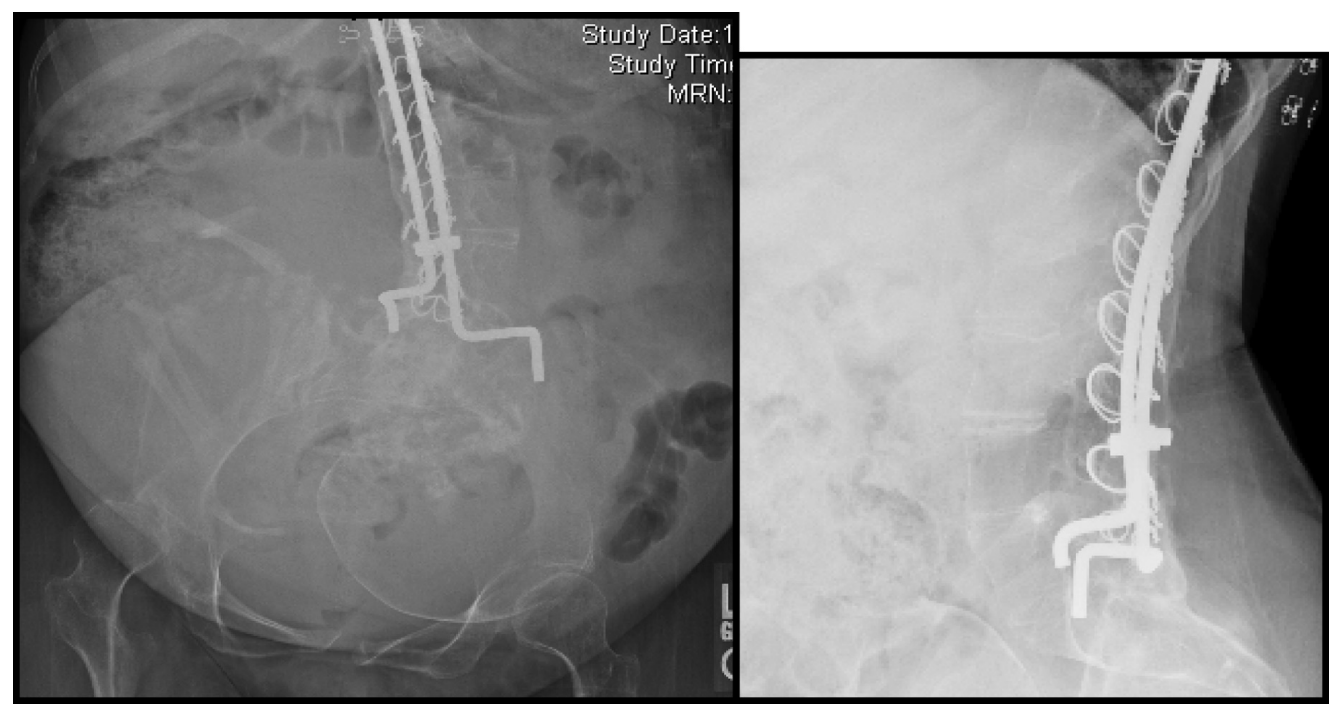

Figure I Anteroposterior and lateral x-ray of pregnant patient with Harrington rods and scoliosis, requesting labor analgesia. 
hole Epidural Catheter) was threaded easily and tested with lidocaine $2 \% 3 \mathrm{~mL}$ and fentanyl $25 \mathrm{mcg}$. Using the pin-prick method, no sensory loss was found at any level, but the patient reported that the contractions she had started to feel were now painless. A patient-controlled epidural analgesia (PCEA) pump with a continuous infusion of bupivacaine $0.0625 \%$ and fentanyl $2 \mu \mathrm{g} / \mathrm{mL}$ at $10 \mathrm{~mL} / \mathrm{h}$ was started, with a setting allowing a $5 \mathrm{~mL}$ bolus every 10 minutes. Despite an asymmetrical sensory block (right thoracal 6-8 dermatomes) over the next 48 hours with the PCEA solution, the patient reported having adequate degree of pain relief. After 72 hours of induction with prostaglandins and augmentation with intravenous oxytocin, and despite regular contractions, cervical dilatation arrested at $4 \mathrm{~cm}$. At that point the decision was made to proceed by cesarean delivery.

Despite a negative aspiration test, the patient reported a metallic taste, tinnitus, and showed slight perioral fasciculations minutes after the catheter was tested with lidocaine $2 \%$ $5 \mathrm{~mL}$, suggestive of an intravascular location of the epidural catheter tip.

In the operating room, several attempts to perform a spinal anesthetic with a Whitacre $25 \mathrm{G}$ in the sitting position were unsuccessful, and using the $17 \mathrm{G}$ Tuohy needle to find the subarachnoid space to perform a continuous spinal anesthetic also failed.

A general anesthetic with rapid sequence induction was administered with propofol $2 \mathrm{mg} / \mathrm{kg}$ and rocuronium $0.9 \mathrm{mg} / \mathrm{kg}$ followed by sevoflurane $0.5 \mathrm{MAC}$ (minimum alveolar concentration) $+\mathrm{N}_{2} \mathrm{O} / \mathrm{O}_{2}$, with fentanyl $2.5 \mu \mathrm{g} / \mathrm{kg}$. The trachea was easily intubated by direct laryngoscopy. A healthy male baby was delivered, requiring no further medical care beyond the normal postnatal pediatric assessment.

Reversal of the muscle relaxant with neostigmine was attempted, once the train-of-four showed four twitches. But as anticipated, a delayed recovery of muscle tone following the nondepolarizing neuromuscular blockade was noted, and the patient remained intubated. We admitted her to the intensive care unit where she was uneventfully extubated 12 hours later.

She reported a generalized muscular weakness and difficulty swallowing for 1 week, nonetheless she was satisfied with the management of her labor and delivery and is now planning a second pregnancy.

\section{Discussion}

This is the first literature review of the anesthetic management of SMA patients in the perinatal period. This case raises several issues, as follows.
SMA effects on the lung during pregnancy are underreported. Severe restrictive lung disease (sRLD) is often present in SMA, and pulmonary function can worsen during pregnancy and may improve again after delivery. ${ }^{7}$ Particularly, the reduction in lung capacities caused by the enlarged uterus and the increased airway pressures during positive pressure ventilation impact pulmonary function negatively. Additionally, fatigue and worsening of muscle function may necessitate ventilatory assistance in the last trimester and/or after general anesthesia. Recovery in the intensive care unit (ICU) was necessary in all reported cases (Table 1). Pulmonary function may reduce even more in the setting of preeclampsia. ${ }^{8}$

SMA and neuraxial anesthesia: Severe scoliosis due to thoracic wall muscle weakness often necessitates (early) corrective surgery (Table 1), which can alter epidural space anatomy resulting in patchy and incomplete blocks due to the unpredictable local anesthetic distributions. In addition, positioning of the wheelchair-bound patient and defining landmarks for block placement can be very complicated.

Ultrasound guidance or fluoroscopic assistance may be helpful for performing a neuraxial blockade. In this case ultrasound was not helpful because of the absence of bony landmarks after laminectomy, extreme kyphosis, torsion (Figure 1) and various epidural anatomical changes after spinal surgery and a fluoroscopic assisted catheter placement was not available at short notice - either for labor analgesia and/ or cesarean-section anesthesia.

With regard to spinal anesthesia, a high block in a supine, scoliotic patient with restrictive lung disease could worsen already marginal pulmonary function, and therefore, choosing the right amount of spinal local anesthetic is crucial. ${ }^{9-11}$

In regards to epidural or continuous spinal catheter, a gentle titration to the desired dermatomal level seems ideal. In patients with a history of previous back surgery with possible obliteration of the epidural space, a spinal catheter may be more reliable. Case reports of successful epidural labor analgesia and anesthesia for cesarean deliveries ${ }^{12,13}$ as well for successful spinal anesthesia exist, but not for continuous spinal catheter.

In regards to general anesthesia, bulbar weakness and cervical spine changes with restricted movement alter the intubation anatomy unfavorably. ${ }^{8}$ These factors increase the risk for a difficult intubation of the trachea and a possible aspiration in a population with a known high incidence of sRLD. These complications carry significant sequelae for patients who often have a history of recurrent pneumonias and prolonged recoveries from general anesthesia. Reviewing the literature, 
Table I Summary of cases and their anesthetic management

\begin{tabular}{|c|c|c|c|c|c|c|}
\hline Case & $\begin{array}{l}\text { SMA-type } \\
\text { Diagnosis modus }\end{array}$ & $\begin{array}{l}\text { Patient } \\
\text { data }\end{array}$ & Medical history & $\begin{array}{l}\text { Obstetric plan and } \\
\text { gestational age }\end{array}$ & Anesthesiological plan & Study \\
\hline I & $\begin{array}{l}\text { SMA II } \\
\text { PCR }\end{array}$ & $\begin{array}{l}32 \text { years } \\
20 \mathrm{~kg}\end{array}$ & $\begin{array}{l}\text { Scoliosis } \\
\text { sRLD } \\
\text { Wheelchair }\end{array}$ & $\begin{array}{l}\text { Elective c/s at } \\
28 \text { weeks }\end{array}$ & $\begin{array}{l}\text { Failed epidural GA with FIO } \\
\text { (Second pregnancy: } \\
\text { GA with FIO) }\end{array}$ & Pugh et $\mathrm{al}^{16}$ \\
\hline 2 & $\begin{array}{l}\text { SMA II } \\
\text { Electrodiagnostic, } \\
\text { Muscle biopsy }\end{array}$ & 28 years & $\begin{array}{l}\text { Scoliosis with surgery } \\
\text { Wheelchair }\end{array}$ & $\begin{array}{l}\text { Elective c/s at } \\
33 \text { weeks }\end{array}$ & $\begin{array}{l}\text { Failed SPA } \\
\text { GA with FIO }\end{array}$ & Habib and Muir ${ }^{17}$ \\
\hline 3 & $\begin{array}{l}\text { SMA II } \\
\text { Electrodiagnostic, } \\
\text { Muscle biopsy }\end{array}$ & 24 years & $\begin{array}{l}\text { Scoliosis with surgery } \\
\text { sRLD } \\
\text { Wheelchair }\end{array}$ & $\begin{array}{l}\text { IOL at } 39 \text { weeks } \\
\text { Vacuum assisted } \\
\text { vaginal delivery }\end{array}$ & Only IV narcotics and LA & $\begin{array}{l}\text { Flunt et } \mathrm{al}^{15} \\
\text { Case } \mathrm{A}\end{array}$ \\
\hline 4 & $\begin{array}{l}\text { SMA II } \\
\text { Electrodiagnostic, } \\
\text { Muscle biopsy }\end{array}$ & 26 years & $\begin{array}{l}\text { Scoliosis with surgery } \\
\text { sRLD } \\
\text { Wheelchair }\end{array}$ & $\begin{array}{l}\text { Elective c/s at } \\
39 \text { weeks }\end{array}$ & GA & $\begin{array}{l}\text { Flunt et al }{ }^{15} \\
\text { Case B }\end{array}$ \\
\hline 5 & $\begin{array}{l}\text { SMA II } \\
\text { PCR }\end{array}$ & $\begin{array}{l}30 \text { years } \\
48 \mathrm{~kg}\end{array}$ & $\begin{array}{l}\text { Scoliosis with surgery } \\
\text { sRLD } \\
\text { Wheelchair }\end{array}$ & $\begin{array}{l}\text { IOL at } 38 \text { weeks } \\
\text { c/s after failed IOL }\end{array}$ & $\begin{array}{l}\text { Failed epidural } \\
\text { Failed SPA } \\
\text { GA } \\
\text { Swallowing difficulties } \\
\text { for I week }\end{array}$ & Our case \\
\hline 6 & SMA IIa & $\begin{array}{l}23 \text { years } \\
37 \mathrm{~kg}\end{array}$ & $\begin{array}{l}\text { Scoliosis with surgery } \\
\text { sRLD } \\
\text { Wheelchair }\end{array}$ & $\begin{array}{l}\text { Elective c/s at } \\
28 \text { weeks }\end{array}$ & $\begin{array}{l}\text { GA and liohypogastric- } \\
\text { ilioinguinal block } \\
\text { postoperative }\end{array}$ & Neumann et $\mathrm{al}^{18}$ \\
\hline 7 & SMA II & 21 years & sRLD & c/s at 37 weeks & $\begin{array}{l}\text { Local infiltrations } \\
\text { ( } 1 \% \text { Lido } 100 \mathrm{~mL}) \\
\text { and analog-sedation }\end{array}$ & Burnett and Halim²! \\
\hline 8 & $\begin{array}{l}\text { SMA }^{b} \\
\text { (probably type II) }\end{array}$ & 20 years & $\begin{array}{l}\text { Scoliosis no surgery } \\
\text { Wheelchair }\end{array}$ & $\begin{array}{l}\text { Elective } \mathrm{c} / \mathrm{s} \text { at } \\
38 \text { weeks }\end{array}$ & SPA & $\begin{array}{l}\text { Harris and } \text { Moaz }^{14} \\
\text { Case A }\end{array}$ \\
\hline 9 & $\begin{array}{l}\text { SMA }^{b} \\
\text { (probably type II) }\end{array}$ & 19 years & Wheelchair & $\begin{array}{l}\text { Elective c/s at } \\
38 \text { weeks }\end{array}$ & SPA & $\begin{array}{l}\text { Harris and } \text { Moaz }^{14} \\
\text { Case B }\end{array}$ \\
\hline 10 & $\begin{array}{l}\text { SMA }^{b} \\
\text { Electrodiagnostic }\end{array}$ & 23 years & $\begin{array}{l}\text { sRLD } \\
\text { Vocal cord paralysis }\end{array}$ & $\begin{array}{l}\text { Vaginal delivery at } \\
38 \text { weeks (forceps) }\end{array}$ & Labor epidural analgesia & Laffargue $^{12}$ \\
\hline $\begin{array}{l}11 \\
12\end{array}$ & $\begin{array}{l}\mathrm{SMA}^{\mathrm{b}} \\
\mathrm{SMA}^{\mathrm{b}}\end{array}$ & $\begin{array}{l}22 \text { years } \\
22 \text { years }\end{array}$ & Wheelchair & $\begin{array}{l}\text { Elective c/s at term } \\
\text { IOL } \\
\text { Vaginal delivery } \\
\text { at } 37 \text { weeks }\end{array}$ & Labor epidural analgesia & $\begin{array}{l}\text { Wilson and Williams" } \\
\text { Wilson and Williams" }\end{array}$ \\
\hline 13 & SMA III & $\begin{array}{l}35 \text { years } \\
\text { g4p0 } \\
41 \mathrm{~kg}\end{array}$ & $\begin{array}{l}\text { Scoliosis with surgery } \\
\text { sRLD } \\
\text { Wheelchair }\end{array}$ & $\begin{array}{l}\text { Elective c/s at } \\
35 \text { weeks }\end{array}$ & $\begin{array}{l}\text { GA with dexmedetomidine } \\
\text { for FIO }\end{array}$ & $\begin{array}{l}\text { McLoughlin and } \\
\text { Bhagvat }^{19}\end{array}$ \\
\hline 14 & $\begin{array}{l}\text { SMA III } \\
\text { Muscle biopsy }\end{array}$ & 33 years & $\begin{array}{l}\text { Scoliosis with surgery } \\
\text { sRLD } \\
\text { Wheelchair }\end{array}$ & $\begin{array}{l}\text { Elective } c / s \text { at } \\
38 \text { weeks }\end{array}$ & $\begin{array}{l}\text { Failed epidural } \\
\text { SPA possible }\end{array}$ & Buettner ${ }^{13, c}$ \\
\hline 15 & SMA III & 38 years & $\begin{array}{l}\text { Scoliosis no surgery } \\
\text { Wheelchair } \\
\text { had failed intubation } \\
\text { with previous } \\
\text { tracheostomy } \\
\text { preeclampsia } \\
\text { at } 28 \text { weeks }\end{array}$ & $\begin{array}{l}\text { Elective } c / s \text { at } \\
3 \text { I weeks }\end{array}$ & $\begin{array}{l}\text { Failed epidural } \\
\text { GA with FIO }\end{array}$ & Kitson ${ }^{9}$ \\
\hline 16 & $\begin{array}{l}\text { SMA III } \\
\text { PCR }\end{array}$ & $\begin{array}{l}24 \text { years } \\
42 \mathrm{~kg}\end{array}$ & $\begin{array}{l}\text { Scoliosis with surgery } \\
\text { sRLD } \\
\text { Wheelchair }\end{array}$ & $\begin{array}{l}\text { Elective c/s at } \\
38 \text { weeks }\end{array}$ & GA & $\begin{array}{l}\text { McLoughlin and } \\
\text { Bhagvat }^{19, c}\end{array}$ \\
\hline 17 & SMA III & $\begin{array}{l}22 \text { years } \\
46 \mathrm{~kg}\end{array}$ & Wheelchair & $\begin{array}{l}\text { c/s for cephalopelvic } \\
\text { disproportion }\end{array}$ & Epidural anesthesia & Wilson and Williams" \\
\hline 18 & SMA III & $\begin{array}{l}22 \text { years } \\
41 \mathrm{~kg}\end{array}$ & & $\begin{array}{l}\text { IOL at } 37 \text { weeks } \\
\text { Vacuum delivery }\end{array}$ & & Wilson and Williams"' \\
\hline
\end{tabular}

Notes: ${ }^{a}$ Diagnostic mode was not mentioned in the study; 'SMA type not referred to in the study; 'Recommended reading.

Abbreviations: c/s, cesarean section; CSE, combined spinal epidural anesthesia; CSF, cerebrospinal fluid; FIO, awake fiber optic guided intubation; GA, general anesthesia; IOL, induction of labor; IV, intravenous; LA, local anesthetics; NDMR, nondepolarizing muscle relaxant; PCR, polymerase chain reaction; SMA II, spinal muscle atrophy type II; SPA, spinal anesthesia; sRLD, severe restrictive lung disease. 
awake fiberoptic guided intubations (FIOs) were chosen in four out of six intubations for planned cesarean sections under general anesthesia on patients with SMA type II and III. ${ }^{9,15,16,18}$ Case reports of local anesthetic infiltration for cesarean section paired with light sedation exist. ${ }^{21}$

Reviewing the case reports with regard to the chosen anesthetic medications (Table 1), propofol was the main induction agent, thiopentone was used in one instance, and the alpha-2 receptors antagonist dexmedetomidine was used to sedate for one awake FIO before cesarean section. ${ }^{18}$ General anesthesia was maintained with either isoflurane or sevoflurane and $\mathrm{N}_{2} \mathrm{O}$.

Analgesia was intraoperatively achieved with alfentanyl or fentanyl, postoperatively by NSAIDs and morphine. In one instance, an iliohypogastric-ilioinguinal nerve block was performed. The usage of the short acting remifentanyl, or postoperative TAP (transversus abdominis plane) blocks were not reported; however, both appear to be good choices to manage intra- and postoperative pain in the setting of neuromuscular pathology and expected respiratory insufficiency.

The nondepolarizing muscle relaxant rocuronium was given in four cases, including this one, and antagonized with neostigmine. However, SMA patients with their underlying muscle weakness and SRLD are very sensitive to nondepolarizing muscle relaxants, and postoperative ventilation was necessary in all cases using rocuronium. One intubation was performed without muscle relaxation and extubated in the operating room after the cesarean section, but like the other cases, the patient recovered in the ICU to allow closer observation. ${ }^{17}$

In no report was sugammadex used. In our case, the drug was not available. Succinylcholine, a depolarizing muscle relaxant, should be avoided after motor neuron lesions. The denervation of the muscle causes an increase in number, surface area, and agonist sensitivity of acetylcholine receptors. Receptor activation results in prolonged opening, allowing intracellular potassium to leak from muscle into plasma and can cause severe hyperkalemia. ${ }^{20}$

Our patient complained of difficulties swallowing for one week. We attributed this to a prolonged recovery after the nondepolarizing muscle blockade by rocuronium. There is no evidence in the literature on SMA effects on the uterine musculature: the uterus is autonomically innervated and is therefore unaffected by the motor neuron disease; normal strength contractions can be expected, and normal vaginal deliveries have been described..$^{8,10,11}$ However, due to possible uterine malposition in the lower abdomen, associated with the anatomical changes inherent to SMA, contractions may not be labor effective. ${ }^{8}$

In our case, this is one possible explanation as to why the induction of labor (IOL) failed.

Learning points of this case report are

- Patients with SMA type II should be planned inductions. If neuraxial labor analgesia or anesthesia for cesarean section is required, ultrasound guidance may be useful; however, fluoroscopic spinal catheter placement should be anticipated and planned.

- If a general anesthesia is required, the intubation should ideally be performed without muscle relaxation.

- An FIO was chosen in most case reports, ICU recovery was necessary in all cases and should be considered.

- IOL may not be effective in patients with SMA due to abdominal uterine malposition.

\section{Note}

This case study was presented in part in Washington, DC at the SOAP annual meeting 2009.

\section{Disclosure}

The authors report no conflicts of interest in this work.

\section{References}

1. Wessel HB. Spinal muscular atrophy. Pediatr Ann. 1989;18: 421-427.

2. Sumner CJ. Therapeutics development for spinal muscular atrophy NeuroRx. 2006;3:235-245.

3. Riessland M, Ackermann B, Forster A, et al. SAHA ameliorates the SMA phenotype in two mouse models for spinal muscular atrophy Hum Mol Genet. 2010;19:1492-1506.

4. Werdnig G. Two early infantile hereditary cases of progressive muscular atrophy simulating dystrophy, but on a neural basis. 1891. Arch Neurol. 1971;25:276-278.

5. Markowitz JA, Tinkle MB, Fischbeck KH. Spinal muscular atrophy in the neonate. J Obstet Gynecol Neonatal Nurs. 2004;33:12-20.

6. Kugelberg E, Welander L. Heredofamilial juvenile muscular atrophy simulating muscular dystrophy. AMA Arch Neurol Psychiatry. 1956; 75:500-509

7. Rudnik-Schoneborn S, Zerres K, Ignatius J, Rietschel M. Pregnancy and spinal muscular atrophy. J Neurol. 1992;239:26-30.

8. Carter GT, Bonekat HW, Milio L. Successful pregnancies in the presence of spinal muscular atrophy: two case reports. Arch Phys Med Rehabil. 1994;75:229-231.

9. Kitson R, Williams V, Howell C. Caesarean section in a parturient with type III spinal muscular atrophy and pre-eclampsia. Anaesthesia. 2004; 59:94-95.

10. Weston LA, DiFazio CA. Labor analgesia and anesthesia in a patient with spinal muscular atrophy and vocal cord paralysis. A rare and unusual case report. Reg Anesth. 1996;21:350-354.

11. Wilson RD, Williams KP. Spinal muscular atrophy and pregnancy. Br J Obstet Gynaecol. 1992;99:516-517. 
12. Laffargue F, Boulot P, Lafont L, Jonquet O, Hedon B, Viala JL. An association of Werdnig-Hoffman disease and pregnancy: apropos of an unusual case. J Gynecol Obstet Biol Reprod (Paris). 1990;19: 321-323.

13. Buettner AU. Anaesthesia for caesarean section in a patient with spinal muscular atrophy. Anaesth Intensive Care. 2003;31:92-94.

14. Harris SJ, Moaz K. Caesarean section conducted under subarachnoid block in two sisters with spinal muscular atrophy. Int J Obstet Anesth. 2002;11:125-127.

15. Flunt D, Andreadis N, Menadue C, Welsh AW. Clinical commentary: obstetric and respiratory management of pregnancy with severe spinal muscular atrophy. Obstet Gynecol Int. 2009;2009:942301.

16. Pugh CP, Healey SK, Crane JM, Young D. Successful pregnancy and spinal muscular atrophy. Obstet Gynecol. 2000;95:1034.

17. Habib AS, Muir HA. Tracheal intubation without muscle relaxants for caesarean section in patients with spinal muscular atrophy. Int $J$ Obstet Anesth. 2005;14:366-367.
18. Neumann MM, Davio MB, Macknet MR, Applegate RL 2nd. Dexmedetomidine for awake fiberoptic intubation in a parturient with spinal muscular atrophy type III for cesarean delivery. Int $J$ Obstet Anesth. 2009;18:403-407.

19. McLoughlin L, Bhagvat P. Anaesthesia for caesarean section in spinal muscular atrophy type III. Int J Obstet Anesth. 2004;13:192-195.

20. Martyn JA, Richtsfeld M. Succinylcholine-induced hyperkalemia in acquired pathologic states: etiologic factors and molecular mechanisms. Anesthesiology. 2006;104:158-169.

21. Burnett T, Halim M. Local anesthetic infiltration for cesarean section in a patient with spinal muscular atrophy type II. In: SOAP 42nd Annual Meeting; May 12-16, 2010; San Antonio, TX. Abstract 132.

\section{Publish your work in this journal}

Local and Regional Anesthesia is an international, peer-reviewed, open access journal publishing on the development, pharmacology, delivery and targeting and clinical use of local and regional anesthetics and analgesics. The journal welcomes submitted papers covering original research, basic science, clinical studies, reviews \& evaluations,

\section{Dovepress}

guidelines, expert opinion and commentary, case reports and extended reports. The manuscript management system is completely online and includes a very quick and fair peer-review system, which is all easy to use. Visit http://www.dovepress.com/testimonials.php to read real quotes from published authors. 